August 6, 2006

\title{
Looting, Law, and Lawlessness
}

\author{
Stuart P. Green
}

\begin{abstract}
:
As recent incidents in the wake of Hurricane Katrina and other natural and man-made disasters have illustrated, the moral content of looting spans an extraordinarily wide continuum: At one end are predatory and exploitative acts that seem deserving of even greater punishment than ordinary acts of burglary and larceny. At the other end are cases of necessity, involving otherwise law-abiding citizens who, as a result of forces beyond their control, find themselves hungry and exposed to the elements. In between these two poles lies a wide range of conduct that often involves impoverished and alienated citizens living on the edges of society, encouraged to engage in lawlessness by powerful group dynamics and the apparent suspension of civil order.

This article begins by examining the various meanings - both literal and metaphorical of looting. It then considers the factors that make "bad looting" so bad, and "good looting" less so. With respect to the latter, it considers the possibility that: (1) the disruption in normal social order might leave defendants in a "state of nature," outside the jurisdictional reach of the court; (2) the defendant's criminal acts were "necessary" in order to avoid some greater harm from occurring; and (3) the otherwise law-abiding offender, suffering from a combination of fright, fatigue, hunger, exposure, and disorientation, should be at least partially excused on the grounds that his acts were "out of character."

The article concludes by considering some of the practical implications of the foregoing analysis, including the suggestion by various "conservative" commentators that the proper response to looters is to "shoot them on sight." It argues that such a policy would be profoundly misguided, both because the criminal law should not tolerate the disproportionate use of deadly force in response to what is essentially a property crime, and because of the obvious difficulties of distinguishing between bad and good looting, particularly under the kinds of emergency conditions in which such acts are committed.
\end{abstract}




\section{Looting, Law, and Lawlessness}

\section{Stuart P. Green*}

Of the countless images of chaos and turmoil that appeared in the media and on the

Internet in the aftermath of Hurricane Katrina, two particular photographs, juxtaposed, stand out: In one of the images, shot by Dave Martin of the Associated Press, a young, dark-skinned man is shown wading through chest-deep waters carrying a full garbage bag and what looks like a case of soda. In the second picture, taken by Chris Graythen of AFP/Getty Images, a light-skinned man and woman are shown, also wading through chest-deep water, also dragging goods behind them. ${ }^{1}$

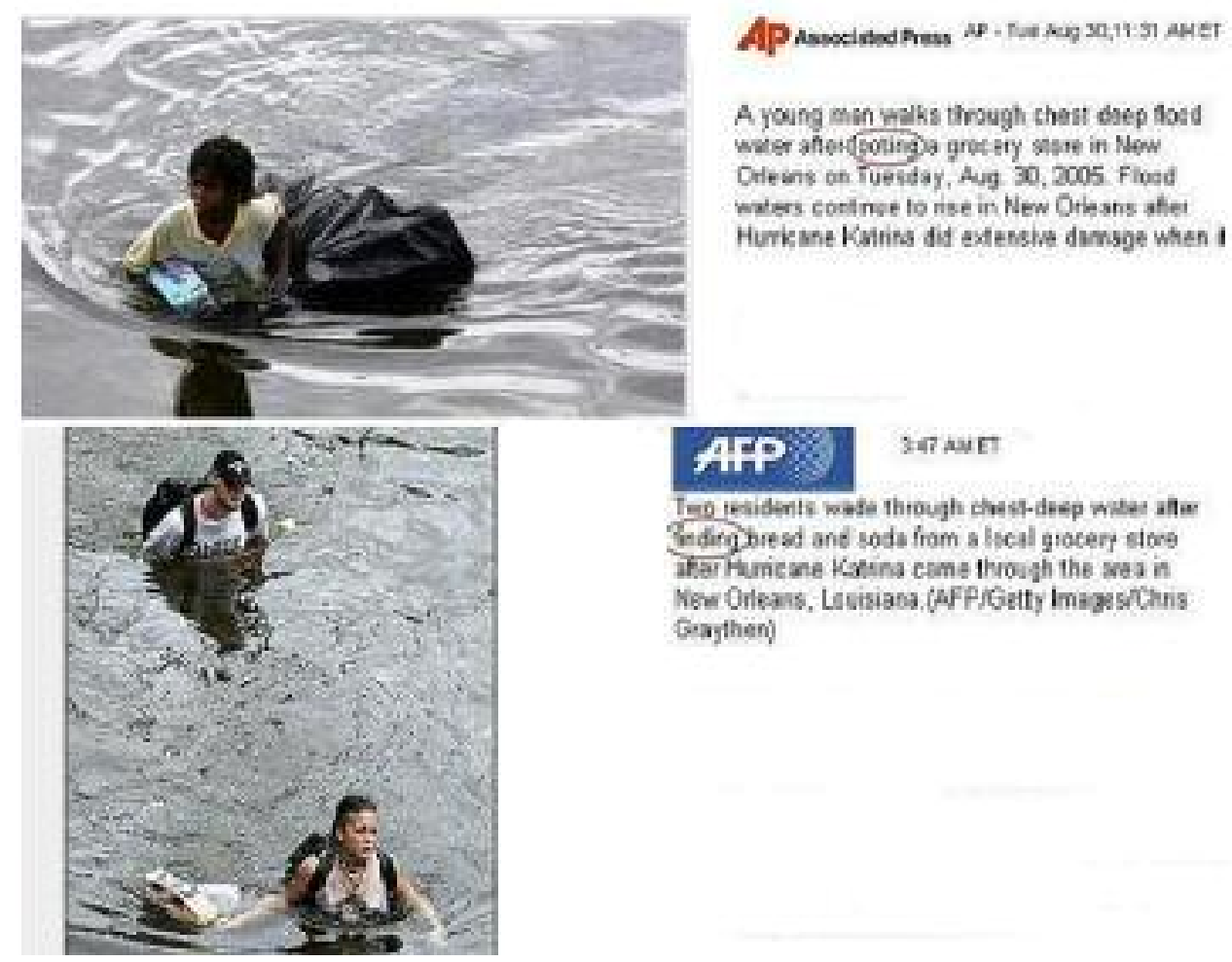

${ }^{*}$ L.B. Porterie Professor of Law, Louisiana State University. An earlier version of this paper was presented to colloquia at the Hebrew University of Jerusalem Faculty of Law and Institute of Criminology and at the University of Notre Dame Law School. I am grateful for the many helpful comments and questions I received.

1 The captioned photos were originally posted on YahooNews.com, but were subsequently removed. 
What is notable about the photographs is not so much the images themselves, but the captions that accompany them. The caption under the Martin photo says that the (dark-skinned) man had been "looting a grocery store in New Orleans," while the caption under the Graythen photo says that the (light-skinned) pair had been "finding bread and soda from [sic] a local grocery store." What is perplexing about these captions is that, based solely on the evidence of the photos, the acts depicted are, in legally relevant ways, virtually indistinguishable.

At least two possible explanations for this discrepancy come to mind. The most straightforward one is that whoever wrote the captions possessed information not immediately evident from the photos themselves. For example, it's possible that the man in the Martin photo had previously been observed stealing items from a store. Similarly, it's possible that the pair in the Graythen photo had spoken to the photographer and explained their plight. A very different sort of explanation - much discussed on Internet blog sites - was that the captions reflect a racist double standard, according to which young black men are presumed to be criminally inclined while young whites are not. ${ }^{2}$ In the larger context of Hurricane Katrina and the shocking ineptness of the governmental response to it - which left a disproportionate number of AfricanAmerican residents of New Orleans abandoned, homeless, and even dead - this explanation has an undeniable resonance.

My interest in these photos lies elsewhere, however. As I shall discuss, the photos and their captions are symptomatic of a broader moral indeterminacy that underlies the act of looting itself. Indeed, as we shall see, looting constitutes a uniquely complex crime type. Its moral

\footnotetext{
2 See Tania Ralli, Hurricane Katrina: The Photographs: Who's a Looter? In Storm's Aftermath, Pictures Kick Up a Different Kind of Tempest, N.Y. TIMES, at C6 (Sept. 5, 2005). It's also worth noting the curious error in syntax in the caption accompanying the Graythen photo - which refers to the couple "finding bread . . from a local grocery." It suggests the possibility that the caption might originally have referred to their "looting bread . . . from a local grocery," and been only partially changed somewhere in the editing process.
} 
content spans an extraordinarily wide continuum: At one end are those heinous cases that seem deserving of even greater punishment than ordinary acts of burglary and larceny -- cases involving urban predators, perhaps already pursuing a life of crime, who use the occasion of a natural disaster or civil unrest to exploit their neighbors at the hour of their greatest vulnerability, carting away goods of types and quantities they could hardly begin to use for themselves, which they plan to sell for a quick profit. At the other end of the continuum are those cases of pure necessity, involving otherwise law-abiding citizens who, as a result of forces beyond their control, find themselves and their families hungry, exposed to the elements, perhaps without needed medicines, forced to break into a grocery store or pharmacy and take only enough to last until the emergency is likely to end. In between these two poles lies a wide range of conduct that often involves impoverished and alienated citizens living on the edges of society, who are encouraged by powerful group dynamics and the apparent suspension of civil order to steal property from what are often heavily insured businesses owned by anonymous shareholders and managed by executives in far-off cities.

My aim in this article is to explore the moral and legal principles that inform the act of looting, and to think more generally about the role of law in times of lawlessness. The occasion for this exploration seems particularly ripe. Although looting of one sort or another has occurred since virtually the beginning of recorded history, it seems to have become more common, or at least more visible, in recent years. Since the turn of the 21 st century, dramatic outbreaks of looting have occurred not only in New Orleans in the wake of Hurricane Katrina; but also in the Kashmir region of Pakistan, following the devastating earthquake there; in Indonesia, in the wake of the tsunami; in Mexico and Cuba, following Hurricane Wilma; in France, during riots 
by angry youths; and even in New York City, after the attacks of September 11th. ${ }^{3}$ Indeed, it now seems practically inevitable that, whenever terrible disaster strikes, looting will follow.

Yet, curiously, the subject of looting has received relatively little attention from scholars, or from legislatures. The social, demographic, and psychological dynamics of looting have been explored by social scientists in a number of studies, ${ }^{4}$ but looting as a distinct criminal act has been almost completely ignored in the academic law literature. ${ }^{5}$ And while looting has been treated as a war crime under international law since the early $1900 \mathrm{~s},{ }^{6}$ only eight states have enacted generalized looting statutes that apply outside the specifically military context, and these statutes are almost never used. ${ }^{7}$

3 Looting Breaks Out in Pakistan Following Powerful Earthquake, N.Y. TIMES (Oct. 10, 2005); France Chipping Away at Riots, CBSNews.Com (Nov. 10, 2005); Looting in Cuba Following Hurricane Wilma, CUBANET (Nov. 3 , 2005), http://www.cubanet.org/CNews/y05/nov05/03e3.htm; Post-Wilma Looting Chaos Strikes Cancun, USATODAY.COM (Oct. 24, 2005), http://www.usatoday.com/weather/2005-10-24-Cancun-looting_x.htm; Riots Leave Paris Burning, THESUN.COM (undated), http://www.thesun.co.uk/article/0,,2-2006130764,00.html; Kate McGeown, Criminals Target Tsunami Victims, BBCNEWS.CoM (Jan. 4, 2005), <http://news.bbc.co.uk/2/hi/asiapacific/4145591.stm>; <http://www.cbsnews.com/stories/2005/11/09/world/main1027399.shtml>; WiLliam LANGEWIESCHE, AMERICAN GROUND: UnBUILDING THE WORLD TRADE CENTER 159 (2002) (contending, controversially, that some firefighters were involved in September 11-related looting near World Trade Center site). But see Russell Dynes \& Enrico L. Quarantelli, What Looting in Civil Disturbances Really Means, in MODERN CRIMINALS 177, 181-85 (James F. Short, Jr., ed. 1970) (arguing that the incidence of looting in American cities is overestimated owing to the misinterpretation of observed behavior, misunderstandings regarding who owns property, overblown estimates by public officials seeking aid, and sensational coverage of disaster situations in the news media).

4 See, e.g., Robert CURVIN AND Bruce Porter, Blackout Looting! (1979) 4-5; Margaret J.G. Abudu, et al., Black Ghetto Violence: A Case Study Inquiry into the Spatial Pattern of Four Los Angeles Riot Event-Types, 44 Social Problems 483 (1997); Dynes \& Quarantelli, supra note 3; Roger Mac Ginty, Looting in the Context of Violent Conflict: A Conceptualisation and Typology, 25 THIRD WORLD Q. 857 (2004); E.L. Quarantelli \& Russell R. Dynes, Property Norms and Looting: Their Patterns in Community Crises, 31 PHYLON 168 (1960); Michael J. Rosenfeld, Celebration, Politics, Selective Looting and Riots: A Micro Level Study of the Bulls Riot of 1992 in Chicago, 44 Social Problems 483 (1997); Ernest H. Wohlenberg, The “Geography of Civility” Revisited: New York Blackout Looting, 1977, 58 ECONOMIC GEOGRAPHY 29 (1982).

5 The one exception is Roger D. Scott, Looting: A Proposal to Enhance the Sanction for Aggravated Property Crime, 11 J. LAW \& POLITICS 129, 147-52 (1995), which is discussed infra notes 30-32 and accompanying text.

6 Looting as a war crime is discussed infra notes 10-17 and accompanying text.

7 The state law of looting is discussed infra notes 23-25 and accompanying text. 
My analysis proceeds in three parts. Part I seeks to define the meanings - both literal and metaphorical -- of the term looting. It considers looting not only in the realm of natural disasters, blackouts, and civil unrest, but also in the context of warfare, the removal of cultural objects, and stealing from corporate and governmental treasuries. An attempt is made to identify the paradigmatic features of looting, while recognizing that the term is also properly used for cases that do not quite fit the paradigm. Looting is viewed as a species of the genus of theft, which is typically characterized by unauthorized entry, misappropriation of property, and, often, concerted action. What distinguishes looting from other forms of theft is a lack of normal security brought on by emergency circumstances, resulting in the unusual vulnerability of its victims and a general loss of social order.

Part II considers the differences between what I call "bad" and "good" looting, and what lies in between. It begins by exploring the nature of bad looting, arguing that such acts, because of their distinctive exploitative and predatory character, constitute a more serious crime than simple burglary or theft. It then considers three possible grounds for mitigation, or even exoneration, in at least some good, or at least "less bad," cases of looting. The first is that the disruption in normal social order left the defendant in a "state of nature," outside the jurisdictional reach of the court. The second is that the defendant's criminal acts were "necessary" in order to avoid some greater harm from occurring. The third is that the otherwise law-abiding offender, suffering from a combination of fright, fatigue, hunger, exposure, and disorientation, committed his acts, "out of character," under the influence of poverty, alienation, and powerful group dynamics.

Part III explores some of the practical implications of the foregoing analysis. It begins by arguing that looting is so complex and multi-faceted a crime that principles of fair labeling and 
accurate classification demand a specialized statute. It then argues that such statutes need to contain a method for grading acts of looting according to their seriousness, subjecting some, particularly bad cases of looting to enhanced penalties, and allowing other, relatively good acts of looting to be exonerated, or at least mitigated. Finally, it considers the appropriate law enforcement response to looting. Various media commentators, such as Peggy Noonan, writing on the op-ed page of the Wall Street Journal, ${ }^{8}$ have suggested that the proper response to looters is to "shoot them on sight." Shooting looters seems also to have been, at least for a time, the official policy of American occupation forces in Iraq. ${ }^{9}$ I argue that such a policy is profoundly misguided, for at least two reasons. First, the criminal law should not tolerate the disproportionate use of deadly force in response to what is essentially a property crime. Second, the obvious difficulty of distinguishing between bad and good looting, particularly under the kinds of emergency conditions in which, by definition, such acts occur, suggests that a policy of shooting looters raises a serious danger of overdeterrence, of racial discrimination, and of unnecessary killing.

\section{The Concept of Looting}

We begin our inquiry into the meaning of looting by examining the multiple contexts in which the term is applied - to the taking of property in the wake of a natural disasters, blackouts, and civil disturbances, as well as to stealing by soldiers and civilians in the midst of war, to the so-called looting of antiquities and other cultural objects, and to the plundering of assets from

\footnotetext{
8 Peggy Noonan, After the Storm, WALL ST. J. (Sept. 1, 2005) (“As for the tragic piggism that is taking place on the streets of New Orleans, it is not unbelievable but it is unforgivable, and I hope the looters are shot.").

9 Patrick E. Tyler, Aftereffects: Security; New Policy in Iraq to Authorize G.I. 's to Shoot Looters, N.Y. TIMES (May 14, 2003), at A1. This policy is discussed infra text accompanying note 88 .
} 
corporate and governmental treasuries. We then turn to a more detailed look at the basic

elements - both legal and moral - of looting in the wake of disasters and civil unrest, which will be our main focus throughout.

Before we can begin our discussion of the meaning of looting, there is one preliminary point that needs to be addressed. To say that $D$ has "looted" is ordinarily to make a negative normative judgment about $D$ 's behavior. From a linguistic standpoint, there is no such thing as looting that is not bad. When acts that would otherwise constitute looting are justified or excused, we would not ordinarily refer to them as "looting." Instead, we would probably say that $D$ had "carried away" or "scavenged" or "foraged" or "found." Indeed, it is just this linguistic fact that explains what it was that made the captioning of the Martin and Graythen photos so controversial.

Nevertheless, in the interest of linguistic efficiency, I shall for present purposes use the term looting in a somewhat artificial, non-pejorative, morally neutral sense. That is, I shall use "looting" to refer to the carrying away of goods belonging to another in a time of natural disaster or civic unrest regardless of whether such carrying away is ultimately determined to be lawful or justified. Hence, the possibility of what I shall refer to somewhat idiosyncratically as "good" looting.

\section{A. Defining "Looting"}

Although our main focus will be looting in the wake of disasters, it will be useful, at this preliminary stage, to survey how the term is used in other contexts as well, if only to see if there is some common quality or set of qualities that underlies all of these uses, and thereby sheds light on what it is that makes looting a morally distinctive act. For a start, we can identify at least 
three senses (other than stealing in the wake of a disaster) in which the term looting has been used.

\section{Looting as an act of warfare}

Historically, the earliest context in which looting is said to have occurred is the military one. The word looting derives via the Hindi lut from the Sanskrit lunt, meaning "to rob."10 The term originally referred to the taking of goods by victorious troops, or sometimes by citizens, during or immediately following warfare, when defeated armies and populations were at their most vulnerable.

Interestingly, looting in this sense was not uniformly viewed as criminal or deviant. Presumably it was viewed as such by those who had their possessions taken. In the eyes of the law, however, looting was viewed as a prerogative, a legitimate form of compensation for otherwise poorly paid soldiers, a bona fide "spoil of war" to which the victors were entitled. ${ }^{11}$ There was a complex system of rules that governed the taking of loot, including rules about the kinds of buildings that could be entered, the kinds of goods that could be taken, the kinds of person affected (soldiers or civilians), and the time frame within which such takings could occur. $^{12}$ It is important to note, however, that such approval of looting applied only in the

\footnotetext{
10 OXFORD ENGLISH DiCTIONARY, entry on "loot."

11 For example, the system of purse money in the English Navy was based on the taking of loot. See generally Donald A. Petrie, The Prize Game: Lawful looting on the High Seas in The Days of Fighting Sail (2001).

12 For a description of the rules concerning looting in the American Revolution, see DAVID HACKETT FISCHER, WASHINGTON'S CROSSING 176-78 (2004).
} 
military context. As Justinian makes clear, looting in the case of civil disaster was prohibited even under Roman law. ${ }^{13}$

\section{Under contemporary international law, however, looting (or "pillage," as it is usually} termed) is uniformly prohibited. The Hague Convention of $1907^{14}$ and the Geneva Convention of $1949^{15}$ make it a crime to take or destroy real or personal property during an occupation unless it is "absolutely necessary."16 Unfortunately, international law offers no explicit definition of "looting" or "pillage." Instead, it says simply that such provisions are "designed to spare people

13 See Dig. 47.9.1-12, translated in 9 THE CIVIL LAW (S.P. Scott trans. 1932). Thanks to Olivia Robinson for bringing these provisions to my attention. There is also a good deal of looting that occurs in the Hebrew Bible, by both the Jews and their enemies. In some cases, such looting seems to have been approved of, so long as it was in the service of God. See, e.g., Joshua 11.14. Where loot was taken for one's personal use, however, it was considered deviant, and could result in the harshest of punishments. See Joshua 7.22-26 (Achan and his family were stoned to death and burned after it was discovered that he had taken loot from the sack of Jericho for his own use). Interestingly, in the Book Esther, the Jews' decision to forgo the opportunity to loot the wealth of Shushan after the defeat of Haman seems to have been intended to show their moral superiority to the Persians. Esther 9.16.

14 Hague Convention No. IV Respecting the Law and Customs of War on Land and Annex Thereto, Oct. 18, 1907, Art. 28 ("The pillage of a town or place, even when taken by assault, is prohibited."), Art. 47 ("Pillage is formally forbidden.").

15 The Geneva Convention Relative to the Protection of Civilian Persons in Time of War, Aug. 12, 1949, art. 33, 6 U.S.T. 3516, 75 U.N.T.S. 287 provides:

The purpose of this Convention is to protect human beings, but it also contains certain provisions concerning property, designed to spare people the suffering resulting from the destruction of their real and personal property (houses, deeds, bonds, etc., furniture, clothing, provisions, tools, etc.). . . .

This prohibition is general in scope. It concerns not only pillage through individual acts without the consent of the military authorities, but also organized pillage, the effects of which are recounted in the histories of former wars, when the booty allocated to each soldier was considered as part of his pay. Paragraph 2 of Article 33 is extremely concise and clear; it leaves no loophole. The High Contracting Parties prohibit the ordering as well as the authorization of pillage. They pledge themselves furthermore to prevent or, if it has commenced, to stop individual pillage. Consequently, they must take all the necessary legislative steps. The prohibition of pillage is applicable to the territory of a Party to the conflict as well as to occupied territories. It guarantees all types of property, whether they belong to private [p.227] persons or to communities or the State. On the other hand, it leaves intact the right of requisition or seizure (6).

${ }^{16}$ Michael M. Schmitt, Law of Belligerent Occupier: Crimes of War, GlOBAL POLICY Forum (April 15, 2003), http://www.globalpolicy.org/security/issues/iraq/attack/law/2003/0415bell.htm. Although occupation authorities may "control" property when necessary to keep it from being used by enemy forces, the owner must be provided a receipt to allow him to later reacquire the property and receive compensation for any damage. Services and property may also be "requisitioned" from the populace for the needs of the occupation forces if ordered by the local commander and paid for in cash, preferably at the time of requisition. Id. See also Geneva Convention, supra note 15. 
the suffering resulting from the destruction of their real and personal property (houses, deeds, bonds, etc., furniture, clothing, provisions, tools, etc.)."17

\section{Removal of cultural objects and natural resources}

Another, related, but somewhat narrower use of the term looting is to refer to the removal of culturally or archaeologically significant objects (as well as precious minerals and other natural resources) from native sites. Although no bright line can be drawn between this kind of looting and the more general form of looting described above, this sort of looting is worth distinguishing, since it is specifically prohibited by the 1954 Hague Convention for the Protection of Cultural Property in the Event of Armed Conflict. ${ }^{18}$ Moreover, from a definitional standpoint, this kind of looting is unique. It is the only form of looting the definition of which takes account of the particular kind of things stolen, in addition to the circumstances in which such stealing occurs.

In recent years, the most notorious case of such looting is that which occurred in the wake of the American invasion of Iraq in 2003. As American troops entered Baghdad on April 9, Iraqi looters began ransacking government buildings, stores, mosques, and private homes, stealing what they could find and defacing symbols of Saddam Hussein's regime. ${ }^{19}$ Among the most dramatic acts of looting were those committed at the Iraqi National Museum. As American

17 Geneva Convention, supra note 15.

181954 Hague Convention for the Protection of Cultural Property in the Event of Armed Conflict, 249 UNTS 240 , art. 4(3).

19 See, e.g., Mary Ellen O'Connell, Occupation Failures and the Legality of Armed Conflict: The Case of Iraqi Cultural Property, 9 ART ANTIQUITY AND LAw 323 (2004); Matthew D. Thurlow, Note, Protecting Cultural Property in Iraq: How American Military Policy Comports with International Law, 8 YALE HUMAN RIGHTS \& DEVELOPMENT L.J. 153 (2005). 
troops stood by, largely idle, rampaging mobs carted off thousands of artifacts from one of the world's great collections of Babylonian, Sumerian, and Assyrian antiquities. ${ }^{20}$

\section{Looting as corruption}

A third way in which the term looting is used is in the context of corporate and white collar crime. Executives are said to have looted corporate bank accounts. Government officials are accused of looting national treasuries or the social security trust fund. A particularly notorious example is the so-called looting of savings and loan institutions that was perpetrated during the 1980 s by figures such as Charles Keating. ${ }^{21}$

Looting of this sort differs from the other forms of looting we have been looking at in at least two ways. First, unlike the other forms of looting, this kind of looting does not necessarily involve the physical taking of tangible property. One can loot a business's treasury, for example, on-line, by diverting corporate assets into one's own bank accounts. Second, whereas looting in the more conventional sense involves victims made vulnerable by natural disaster, war, or political instability, looting in the white collar sense involves victims who are exploited by a person who occupies a position of trust, usually a government official or corporate insider. ${ }^{22}$ Given these differences, it may make sense to understand the white collar sense of the term looting as less literal than metaphorical.

\footnotetext{
20 Thurlow, supra note 19. Initial reports estimated the loss at 170,000 objects. Subsequent estimates were far lower, in the range of 8,000-18,000 objects, 33 of which were considered "major." Id.

21 See, e.g., William K. Black, The Best Way to RoB a BANK IS to OWn One: How Corporate ExecUtives AND POLITICIANS LOOTED THE S\&L INDUSTRY (2005).

22 Perhaps an argument could be made that looting in the white collar sense involves a kind of indiscriminate taking that is not present in the case of other kinds of looting.
} 


\section{B. Looting in the Wake of Natural Disasters and Civil Disturbances}

Having looked at looting in the context of warfare, cultural objects, and corruption, we can now turn to our main focus of interest - looting in the wake of a natural disaster or civil unrest. In seeking the paradigmatic features of such criminality, the most obvious place to look is to statutory law. Somewhat surprisingly, however, only seven U.S. states currently have a distinct, generally applicable crime of looting, and, as I shall now discuss, those statutes fail to capture the full sense of what makes looting a distinctive crime.

The states with civilian looting statutes are California, Hawaii, Illinois, Louisiana, Mississippi, North Carolina, and South Carolina. ${ }^{23}$ Such statutes typically impose penalties that are greater than those for ordinary burglary and theft, and in some cases require restitution and community service. ${ }^{24}$ Twenty-seven states and Guam also have anti-looting provisions that apply specifically to their national guard troops. ${ }^{25}$ Looting is also a distinct offense in a number of other countries as well, including Argentina, France, and Israel. ${ }^{26}$ I will have more to say

23 Cal. Penal Code $\S 463$; Hawaii Rev. Stat. Ill. Comp. Stat. Ann. §§ 720 ILCS 5/42-1, 5/42-2; La. Stat. Ann. § 14:62; Miss. Code. Ann. § 97-17-65; N.C. Gen. Stat. § 14-288.6; S.C. Code Ann. § 16-7-10. Tennessee's looting statute, Tenn. Code $\S 39-6-324$, which was similar to Mississippi's, was repealed in 1989 as part of a larger statutory revision. Looting legislation was recently proposed in Florida (apparently in response to recent hurricane-related looting there), but has not yet been enacted. There is no specialized looting provision in the Model Penal Code. The statutes in Illinois, Mississippi, North Carolina, South Carolina, and Tennessee were enacted in the late 1960s at the height of race riots across the United States. The California statute was enacted following the 1989 San Francisco earthquake. Scott, supra note 5, at 153. The Hawaii and Louisiana statutes do not appear tied to any particular historical events.

24 The penalty for looting in Louisiana and Mississippi is fifteen years in prison. One hundred hours of community service is required by the Illinois statute.

25 Ariz. Rev. Stat. A.R.S. § 26-1103; Arkansas Code A.C.A. § 12-64-827; Colo. Rev. Stat. C.R.S.A. § 28-3.1-527; Conn. Gen. Stat. § 27-242; Del.Code § 20:3128; Ga. Code Ann., § 38-2-536; 10 Guam C.A. § 63723.26; Hawaii Rev. Stat. § 124A-138; Idaho Code § 46-1171; Iowa Code Ann. § 29B.100; Kansas Stat. Ann. § 48-3028; Kentucky KRS § 35.620; Louisiana Rev. Stat. § 29:203; Mich. Comp. Laws Ann. § 32.1103; Miss. Code Ann. § 33-13-505; Missouri Stat. § 40.340; Nebraska Rev. Stat. § 55-468; Nevada Rev. Stat. § 412.518; New Mexico Stat. Ann. § 2012-38; New York (McKinney's) Military Law § 130.99; Ohio Rev. Code § 5924.103; Oklahoma St.Ann. § 44:3028; Oregon O.R.S. § 398.356; Pa. 51 Pa.C.S.A. § 6027; Rhode Island Gen.Laws § 30-13-103; South Carolina Code § 25-1-2995; Wash. Rev. Code §38.38.732; W. Va. Code, § 15-1E-104.

26 CÓde Pen. Arts. 163, 167 (Argentina); C. PÉN. Art. 311.4, $8^{\circ}$ (France); Penal LaW OF IsRaeL 
below about whether there is a need for a specialized looting statute. For the moment, I shall simply note that in states without specialized looting statutes, the act is typically prosecuted as a form of aggravated theft or larceny. And even in those states that do have specialized looting provisions, such statutes are rarely, if ever, used. Indeed, it is striking that such statutes seem to have resulted in not a single reported case of prosecution. ${ }^{27}$

The statutes typically require that, in order to commit looting, the defendant must: (1) make an unauthorized entry into a home or business; (2) in which normal security of property is not present by virtue of some natural disaster or civil disturbance (and in which potential victims are therefore made more vulnerable); and (3) thereby obtain control over, damage, or remove the property of another. It is worth asking both the extent to which each of these elements should be regarded as essential to our conception of looting, and whether there are additional characteristics that should be included as well. As I will suggest, a fuller account of looting would also consider: (4) the collective character of much looting. Let us consider each element in turn.

\section{Unauthorized entry into home or business}

Looting statutes typically require that the perpetrator make an unlawful entry into a home or business, or other unlawful trespass onto premises, before committing some additional criminal act (usually taking, damaging, destroying, or exerting control over some property). In American statutory law, therefore, looting requires not just the taking of or damaging property (in conditions of emergency), but also an unlawful entry prior to such taking.

\footnotetext{
27 For some speculation as to why there are both so few looting statutes and so few prosecutions under such statutes, see Scott, supra note 5, at 156-57.
} 
We need to ask, however, whether the concept of looting should necessarily entail an unauthorized entry or trespass. One can easily imagine a case in which an offender, in the aftermath of a storm or earthquake, takes the property of another without making an unlawful entry. For example, she might steal valuable items from the corpses of earthquake victims, or from the ruins of a burned-out building (where entry might not necessarily constitute trespass), or from a relief agency's cache of supplies kept temporarily in open air. Such acts would seem to satisfy the common sense conception of looting, even if they did not satisfy its statutory requirements. So, at least with respect to the element of entry, the statutory definition of looting is arguably too narrow.

\section{Stealing and other post-entry acts against property rights}

Looting involves more than simply unlawful entry into another's property. The looter must also commit some additional criminal act once inside. But the question is what that additional act should be. The statutes typically require that, in addition to making an unlawful entry, the offender also "take," "obtain," "exert control over," "damage," or "destroy" another's "property." It is worth asking whether the concept of looting should also include cases in which an intruder enters a home or business in which normal security is not present and commits a rape or murder, rather than a theft or destruction of property.

As a linguistic matter, it seems problematic to say that one who enters a home or business to commit a rape or murder or other violent offense is "looting." The term loot, like the terms pillage, rapine, and sack has always been associated with the taking of goods. As serious a crime as looting undoubtedly is, it would seem odd to use the term looter to refer someone who 
commits the more serious offense of rape or murder. Certainly, rape and murder lack the moral ambiguity that, I am arguing, is characteristic of looting.

Assuming that I am correct, and that the looter must commit some property crime once inside, there is an additional question whether it is sufficient for the looter to borrow or vandalize or destroy such property, rather than steal it. Once again, language and etymology are helpful here. The noun loot clearly connotes the idea that goods or money have been taken. ${ }^{28}$ It would seem strange to refer to as "loot" property that has been merely damaged, borrowed, or destroyed. Thus, we might think that, with respect to this element, the statutes define looting too broadly.

Indeed, it may be helpful to think of looting as, essentially, a particular form of theft. The term theft refers not to the unlawful borrowing or destruction of property (we use the terms joyriding and vandalism, respectively, to refer to those acts), but rather to its complete misappropriation. At common law, theft could be committed in a variety of ways: by stealth (larceny), deception (false pretenses), coercion (extortion), breach of trust (embezzlement), and so on. To be sure, the modern trend towards consolidation, exemplified most famously by Section 223.1 of the Model Penal Code, has blurred important moral distinctions that such differentiation traditionally reflected. ${ }^{29}$ For the moment, however, my argument is simply that looting involves the unlawful misappropriation of property in a way that is morally distinguishable from all of the other ways of unlawfully misappropriating property, and that looting therefore ought to be treated as a separate and distinct offense -- we can think of it as a

28 See, e.g., OXFORD ENGLISH DICTIONARY (defining "loot" as "[g]oods (esp. articles of considerable value) taken from an enemy, a captured city, etc. in time of war; also, in wider sense, something taken by force or with violence; booty, plunder, spoil").

29 In a book-in-progress tentatively titled PROPERTY, CRIME AND MORALS: ThEFT LAW IN THE INFORMATION AGE, I intend to argue that important moral distinctions between theft by stealth, theft by coercion, theft by deception, and the like justify a return to a regime in which the traditional theft offenses are kept separate. 
kind of "theft in circumstances of emergency" -- rather than merely as a subtype of larceny or burglary.

\section{Group criminality}

In what appears to be the only previous extended discussion of the law of looting, Roger Scott argues that one of the key elements of the offense is its collective or group character. ${ }^{30}$ While Scott concedes that "[n]ot all looting is committed by multiple perpetrators" (and indeed none of the looting statutes actually requires concerted action), he nevertheless contends that "the majority of incidents considered 'looting' are perpetrated by groups, from as few as a dozen actors to as many as thousands." ${ }^{31}$ Scott argues that looting is analogous to crimes such as conspiracy and racketeering in that it poses the special kind of danger that is associated with group criminality. This is one of the reasons, he says, that looting should be regarded as more harmful and more culpable (and should therefore be subject to higher penalties) than other theftrelated crimes. ${ }^{32}$

There are two problems with Scott's argument. First, he fails to recognize the distinction that has been made in the social science literature between looting in the wake of natural disasters and looting in the wake of civil disturbances. As studies by researchers such as E.L. Quarantelli and Russell Dynes suggest, it is only the latter form of looting that is typically perpetrated in groups; looting in the wake of natural disorders is usually done alone. ${ }^{33}$ Second,

\footnotetext{
30 Scott, supra note 5, at 147-52.

31 Id. at 152.

32 Id. at 150 .

33 Quarantelli \& Dynes, supra note 4. There are other differences as well. First, looting in civil disturbances tends to be more widespread than looting in the wake of natural disasters in the sense that it involves a broader segment of the population in terms of age and socio-economic status. Second, looting in natural disasters is committed by
} 
his analysis seems mistaken even with respect to civil disturbance looting. To be sure, such looting does reflect a complex social dynamic: For example, according to various accounts of the New York City blackout of 1977, the first wave of looting was conducted by professional criminals who broke into stores within minutes of the blackout and took the most desirable merchandise; the second wave consisted of alienated youths and poor, unemployed young adults; and the final wave, occurring several hours after the blackout began, involved "“stable poor and working class members of the community who were caught up in the near hysteria of the streets.",34 But to say that civil disorder looting reflects an aggregative, "everyone-else-isdoing-it" quality is only to say that it frequently occurs in groups, not that it is necessarily committed by groups. The difference lies in the fact that civil disorder looting, unlike conspiracy (which, by definition, requires an agreement), only rarely involves action that can properly be characterized as coordinated. ${ }^{35}$

\section{Absence of normal security of property}

Looting statutes typically require that the offense be committed in circumstances "in which normal security of property is not present." 36 Ordinarily, such lack of normal security is the result of a "hurricane, flood, fire, act of God, or force majeure of any kind, or by virtue of a

people who live both inside and outside the community (including, sometimes, the security forces who are sent in to prevent such behavior), whereas in civil disorders it is almost exclusively engaged in by local residents. Third, looting in civil disturbances tends to be focused on retail stores, as opposed to offices, schools, private homes, and factories, and such looters tend to be more "selective" with respect to the kinds of goods they steal than in the case of natural disasters. Fourth, looting in civil disturbances tends to be committed much more open than in the case of natural disasters; looters take goods in full view of others, bystanders, participants, and even police officers. Id. at 174.

34 Id. at 40 (quoting Robert Curvin \& Bruce Porter, Blackout LoOting! NeW York City, July 13, 1977 (1979) 6-7).

35 Looters who do coordinate their activities could of course be prosecuted for conspiracy to commit looting.

36 E.g., Louisiana Rev. Stat. § 14:62. 
riot, mob, or other human agency." Even celebrations over sporting events have prompted large scale riots and looting. ${ }^{37}$

It is ultimately the absence of normal security brought on by an emergency that distinguishes looting from a range of "everyday" offenses such as burglary, theft, and conspiracy, potentially removes it even from the realm of law itself, and contributes to its bewildering moral complexity. In some cases, as we shall see, the emergency will make the looter's stealing a necessity, and thereby mitigate the wrongfulness of her act. In other cases, the disaster will make the looter's potential victims more vulnerable. Hurricanes and other disasters cause the loss of power, lighting, telephone service, and burglar alarms. Walls and doors are blown away or burned down; unusual demands are placed on police and other rescue personnel; residents are forced to leave their property unattended to find safety elsewhere. Other things being equal, therefore, victims whose property lacks normal security are likely to be more vulnerable than victims whose property does not lack normal security. To the extent that looters are aware of this fact, ${ }^{38}$ the wrongfulness of their act would be increased.

\section{The Moral Content of Looting}

Having looked at the various meanings of looting in Part I, we are now in a position to untangle its complex moral content. The basic problem is as follows: Every act that might be called looting involves the same basic elements: (1) an unauthorized entry, (2) the taking or destruction of property, and (3) circumstances in which normal security of property is not present

\footnotetext{
37 See Rosenfeld, supra note 4.

38 There is an interesting question whether an "ordinary burglar" who arrives in town after a natural disaster has hit and is somehow unaware that security is less than usual would be guilty of looting. My instinct is that he would not - that looting requires that the offender be aware that normal security is not present. My thanks to Antony Duff for raising this point.
} 
by virtue of some natural disaster or civil disturbance. But not all of these acts are morally equivalent. The question to be considered here is: how do we sort out those cases of looting that are "bad" from those that are "good" and from those that are "in between"?

\section{A. Bad Looting}

What is it about looting that tends to evoke such a strongly negative emotional response? Why is the term looting so often used pejoratively, to denote acts that are viewed as even more culpable than ordinary theft? Why do some people believe that looters should be "shot on sight"? The answer, I believe, is that those cases of looting that make the strongest impression in the public's consciousness, and are most publicized by the media, are precisely those that are the most shocking and reprehensible. ${ }^{39}$ When the public thinks of looting, what it typically has in mind are the most blameworthy of cases, in which bands of marauding youths crash through the plate glass windows of local stores, carting away electronic equipment, liquor, and jewelry. Such looters, it would seem, are motivated not by the urge to survive, but by greed and opportunism.

Natural disasters like hurricanes and earthquakes often cause great loss and suffering in their victims. The natural and healthy human response to those who are suffering is pity or compassion. As events like Hurricane Katrina and those of September 11 illustrate, many people respond to such suffering heroically. ${ }^{40}$ The bad looter has exactly the opposite reaction: At the very moment when morality demands kindness and caring, even self-sacrifice, he responds with

\footnotetext{
39 See Kathleen Tierney, et al., Metaphors Matter: Disaster Myths, Media Frames, and Their Consequences in Hurricane Katrina, 604 AnNALS AM. ACAD. PoL. \& SOC. SCI. _ (2006).

40 See, e.g., Havidán Rodríduez, et al., "Rising to the Challenges of a Catastrophe: The Emergent and Prosocial Behavior following Hurricane Katrina,” 604 ANNALS AM. ACAD. POL. \& SoC. SCI. _ (2006).
} 
selfishness. He preys on and exploits the plight of his fellow human beings. At its worst, the looter's acts might be characterized as a form of cruelty, which has a claim to being the greatest of all evils. $^{41}$

Looting of this sort also causes fear and resentment in those who are exposed to it. The looter strikes at just the moment when his neighbors are most in need. His actions are accompanied by broken glass and bashed-in doors, even fire. The act is raw and committed without shame, in the open. It aggravates the misery and anxiety that the triggering disaster has already caused.

Further, the looter expresses a disregard for the law, an embrace of anarchy. Looting is disturbing because it reminds us of the apparent fragility of our social contract. Beneath the thin crust of civilization, it is said, "lurks a savage animal that will emerge under stress circumstances." ${ }^{42}$ Bad looting is the product of an inversion of moral norms in which what is normally illicit becomes licit. Lawlessness is not only tolerated, but encouraged. Looting shakes the confidence we feel in our social institutions, and, perhaps more generally, the faith we have in our fellow human beings.

\section{B. Looting in a "State of Nature"}

Having considered the kind of looting that is deserving of even greater blame than ordinary acts of theft and trespass, we now turn our attention to those circumstances that might exempt looting from criminal punishment, or at least mitigate its wrongfulness. We begin with the possibility that the circumstances in which much looting occurs - namely, major disasters

\footnotetext{
41 For a stimulating argument to this effect, see JUDITH N. SHKLAR, ORDINARY VICES 7-44 (1984).

42 Quarantelli and Dynes, supra note 4, at 169 (criticizing this view).
} 
that leave citizens arguably beyond the scope of ordinary law and social norms - would make charges of looting "non-justiciable."

An argument of this sort first seems to have appeared in Lon Fuller's famous fictitious Case of the Speluncean Explorers. ${ }^{43}$ The case involves a group of spelunkers in the Commonwealth of Newgarth, who are trapped in a cave by a landslide. As they approach the point of starvation, they make radio contact with a rescue team. They are told that the rescue will take another ten days and that, unless they obtain nourishment, they will surely die. With no one at the rescue camp willing to advise them as to what they should do, the men turn off the radio, hold a lottery, kill the loser (one Whetmore), eat his body, and survive. When they are rescued, they are prosecuted for murder, which in Newgarth carries a mandatory death penalty. The question, of course, is whether they should have a defense.

One of Fuller's fictitious judges, Foster, J., argues as follows:

$[\mathrm{P}]$ ositive law is predicated on the possibility of men's coexistence in society. When a situation arises in which the coexistence of men becomes impossible, then a condition that underlies all of our precedents and statutes has ceased to exist. When that condition disappears ... the force of our positive law disappears with it... .

Had the tragic events of this case taken place a mile beyond the territorial limits of our Commonwealth, no one would pretend that our law was applicable to them. We recognize that jurisdiction rests on a territorial basis. ... Now I contend that a case may be removed morally from the force of a legal order, as well as geographically. If we look to the purposes of law and government, and to the premises underlying our positive law, these men when they made their fateful decision were as remote from our legal order as if they had been a thousand miles beyond our boundaries. . .

I conclude, therefore, that at the time Roger Whetmore's life was ended by these defendants, they were, to use the quaint language of nineteenth-century writers, not in a "state of civil society" but in a "state of nature." This has the consequence that the law applicable to them is not the enacted and established law of this Commonwealth, but the

43 Lon Fuller, The Case of the Speluncean Explorers, 62 HARV. L. REV. 616, _ (1949). 
law derived from those principles that were appropriate to their condition. I have no hesitancy in saying that under those principles they were guiltless of any crime. ${ }^{44}$

Note that the argument here is different from the usual justification or excuse defenses (considered below), both of which operate within the parameters of the criminal law. Here, the defendant is arguing not that he should win the case on its merits, but that the case is nonjusticiable, that it lies outside the competence of the court.

The crime that Fuller's judge has in mind, of course, is murder. If Fuller's argument applies to the most serious of crimes, then we might think that it would apply a fortiori to the lesser offense as theft. As Andrew von Hirsch puts it, "The criminal code of any civilized country is written on the assumption that certain social institutions exist. A citizen should not steal but avail himself of existing permissible means of earning his own living; he should not commit assault but settle grievances through law, and so on." ${ }^{45}$ In the wake of extraordinary situations like those brought on by hurricanes and earthquakes, the argument goes, the institutions which the criminal law presupposes are absent and the law can no longer sensibly apply. As von Hirsch argues, "[i]t makes no sense to try to compel people to behave like civilized individuals when the minimum requirements of civilization are lacking." ${ }^{, 46}$

There are, however, several problems with the argument from non-justiciability. First, the state of nature, as traditionally conceived (most famously by Hobbes), refers to the hypothetical condition of humanity before the state is established and positive law comes into being. ${ }^{47}$ One who has already grown up in human society and had her behavior shaped by

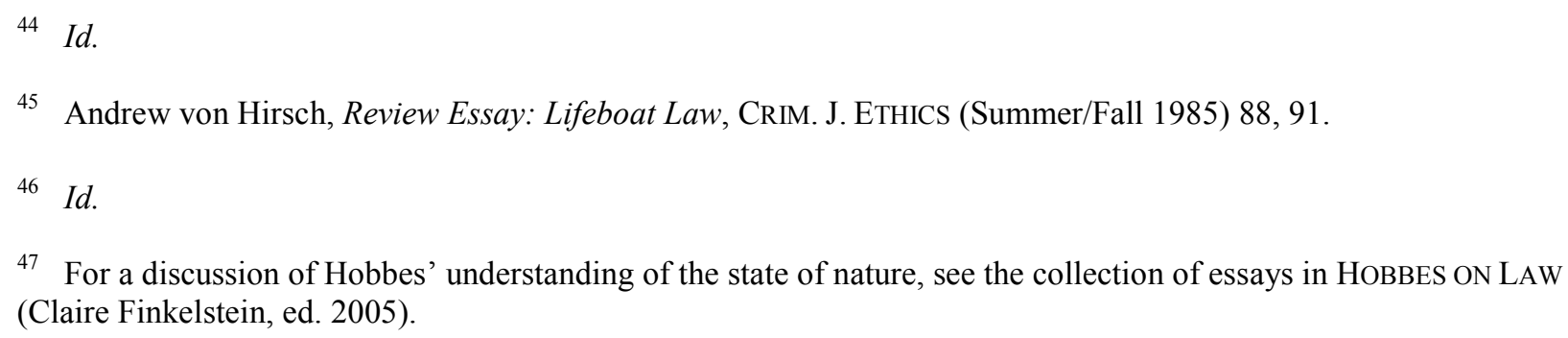


prevailing norms cannot then step outside of society just because she finds herself in the middle of a hurricane. ${ }^{48}$ Society may ultimately decide that the defendant's plight entitles her to special consideration, including perhaps a defense to criminal charges, but that is very different from saying that she is not subject to society's laws and norms in the first place.

Second, the argument proves too much. As von Hirsch himself concedes, “[p]rosecution would be dismissed not only for actions taken to save defendants' own lives but for any other act (however seemingly needless or barbaric) committed while the emergency existed. ${ }^{49}$ The fact that the defendant's act was unnecessary would be irrelevant. Thus, even a defendant who used the occasion of an extreme emergency to commit a crime such as rape would be exempt from criminal liability - an outcome that would seem morally unacceptable.

Nor, it seems, can the argument from non-justiciability be salvaged by contending not that all law is temporarily suspended but only that the laws regarding the ownership of property are suspended. An argument of this sort is offered by the sociologists Dynes and Quarantelli. ${ }^{50}$ It runs as follows: Our law of property presupposes a shared understanding about who can do what with the valued resources of the community. When a devastating hurricane or earthquake strikes, property rights are redefined. What was once the property of individuals becomes the property of the community generally. With individual property rights suspended, they say, “appropriation of private resources - which would normally be considered looting - is temporarily condoned.",51

\footnotetext{
48 A similar point is made by John T. Parry, The Virtue of Necessity: Reshaping Culpability and the Rule of Law, 36 HOUSTON L. REV. 397, 399 (1999).

49 Von Hirsch, supra note 37, at 91.

50 Dynes and Quarantelli, supra note 4, at 185.

$51 \quad I d$.
} 
This argument, although perhaps superficially appealing, suffers from the same kind of defect as the more general argument from non-justiciability. Taken to its logical conclusion, it would exempt from criminal liability not only the more sympathetic cases of "justified" or "excused" acts of looting but also the most heinous acts of looting - those perpetrated by professional criminals who themselves are in no distress but who use the occasion of a natural disaster to prey on their fellow citizens. Assuming that we would want to hold "bad" looters of this sort accountable for their acts, we need some more nuanced, fact-specific approach for exempting "less bad" looters from criminal liability.

\section{Necessity Defense}

When a defendant argues that he was justified in committing some putatively criminal act, he is arguing that even though he did in fact commit all of the requisite acts, he nonetheless did nothing morally wrong. This is so because the crime's definition of prohibited conduct is, in a sense, incomplete. ${ }^{52}$ Contemporary law permits what the crime as-defined otherwise prohibits where circumstances make his action the right (or at least not the wrong ${ }^{53}$ ) thing to do. ${ }^{54}$ As the Model Penal Code Commentary puts it, "[a] speed limit may be violated in pursuing a suspected

\footnotetext{
52 The idea of "incompleteness" in this context is suggested by Sanford Kadish, Excusing Crime, 75 CAL. L. REV. 257,258 (1987).

53 One can certainly imagine a case in which a person who would be justified in looting would nevertheless not do the wrong thing by not looting.

54 Id. The most familiar generalized justification defense is that found in Section 3.02 of the Model Penal Code. Model PenAl CODE $\$ 3.02$ ("conduct that the actor believes to be necessary to avoid a harm or evil to himself or to another is justifiable, provided that ... the harm or evil sought to be avoided by such conduct is greater than that sought to be prevented by the law defining the offense charged"). It should be noted that necessity has not always been recognized as a defense in Anglo-American law, even in the case of property crimes. For example, in Queen $v$. Dudley \& Stephens, 14 Q.B.D. 273, 286 (1884), the court accepted as a given Matthew Hale's statement that it was not the law of England that a starving man could steal a loaf of bread. German and French law, however, were both more receptive to necessity as a defense to theft early on. See GeOrge Fletcher, Rethinking Criminal Law 822 (1978).
} 
criminal. An ambulance may pass a traffic light. . . A druggist may dispense a drug without the requisite prescription to alleviate grave distress in an emergency." ${ }^{55}$ Sometimes the offense provision itself will specify conditions in which the defendant's act will be considered justified. ${ }^{56}$ More commonly, the defendant will have to rely on a generalized "necessity" or "choice of evils" defense provision.

So are there cases in which a person who has engaged in conduct that satisfies the statutory definition of looting would be entitled to a defense of necessity? Imagine a case in which a person is stranded without food or water in the aftermath a hurricane or earthquake, with no rescue in sight. He breaks into a grocery store and carries away enough food to survive for several days. Under one conceptual frame, it seems clear that looting of this sort would be justified. Indeed, the case is reminiscent of the classic Model Penal Code paradigm case, in which a hiker, stranded in a snowstorm without food, breaks into another's cabin to find shelter and obtain sustenance. ${ }^{57}$ The looter has violated the prohibition against trespassing and theft, but he has nonetheless done the right (or at least not the wrong) thing, since he has saved a life (his own) by doing so, at a relatively low cost to the cabin's owner (namely, the loss of food and whatever minimal damage is caused to the window or door through which the looter entered).

But the calculation of evils prevented, and evils caused, is actually more complicated than this simple account would suggest. The most direct harms caused by the offender's looting

55 MPC Commentary to $\S 3.02$, at 9-10.

56 For example, prison escape is defined, on one formulation, as "the intentional departure, under circumstances wherein human life is not endangered, of a person imprisoned, committed, or detained from a place where such person is legally confined." La. Rev. Stat. $\S 14: 110$ (emphasis added). This statute thus explicitly includes an exception for certain justified cases of escape. The defendant would thus not be liable at least in those cases where the prison was on fire or was being flooded.

57 MPC Commentary to $\S 3.02$, at 9. Of course, looting also involves circumstances that are not present in the case of the hiker, including the wider context of disorder, an especially vulnerable victim, and perhaps a plurality of acts or agents. 
are those suffered by the person or entity whose premises are looted. Less direct harms accrue to the community generally -- the loss of civil order and the sense of fear that such loss is likely to cause. We must also consider the possibility that looting tends to be contagious: others in the community might be encouraged by the offender's acts to engage in similar, perhaps less clearly justified, conduct. And such looting might also cause more remote, but still significant harms: for example, the store whose goods were looted might have its insurance premiums increased; as a result, it might decide to raise its prices or even close for good; the premises might remain vacant and boarded up; the incident might mark the beginning of the community's slide into decline.

One of the difficulties here is that comparing harms requires potentially difficult normative judgments. It's easy to see that, other things being equal, it should be permissible to cause ten dollars in property damage in order to prevent a million dollars worth of such damage. But by what yardstick are we to compare incommensurable evils, such as, on the one hand, the hunger that is alleviated by the looter's stealing food and, on the other, the disorder in the community to which his looting might contribute? ${ }^{58}$ And such calculations are made even more complicated by deontological constraints on certain forms of behavior. ${ }^{59}$ For example, even if, in a straight-up comparison, we would always choose the minor loss of property over hunger and possible starvation, our repugnance to stealing and social chaos might be such that we would disapprove of such conduct even if hunger could be alleviated as a result.

\footnotetext{
58 A similar point is made by Parry, supra note 48, at 415-20.

59 See Larry Alexander, Lesser Evils: A Closer Look at the Paradigmatic Justification, 24 LAW AND PHILOSOPHY 611,613 (2005). The best example of such deontological constraints comes in the context of using torture to prevent a terrorist attack.
} 
There are other factors as well that might complicate the analysis. We would want to know not only the seriousness of the potential harm to the defendant, but also its probability. At common law, the necessity defense traditionally required proof of imminence. The Model Penal Code has eliminated this requirement, but some notion of probability nevertheless seems implicit in the concept of "necessity." In addition, the law of necessity has traditionally required both that there be no legal means of averting the harm and that the offender have had no fault in creating the necessitous situation. In the context of our looting hypothetical, we would thus want to know the extent to which relief might have been "on the way," and whether the offender somehow contributed to his plight (for example, by failing to abide by a mandatory evacuation order prior to the storm)

Much of the scholarly debate over the rationale for, and limits of, the necessity defense has focused on those cases in which the crime committed to avoid some greater harm from occurring is homicide. (In such cases, the defendant invariably kills a single victim in order to avoid the deaths of multiple victims. ${ }^{60}$ ) But with respect to the lesser charges of trespass and theft, scholars have more or less assumed that necessity will, in appropriate cases, provide a complete defense. ${ }^{61}$ Indeed, as noted, the case of the lost and starving hiker who breaks into a cabin in the wilderness to obtain food and other basic provisions is often viewed as the paradigm case of necessity, the uncontested hypothetical that is given in the Model Penal Code

\footnotetext{
60 The leading cases, discussed in a seemingly endless procession of law review articles, are Dudley and Stephens [1884] 14 QBD 273 DC, and United States v. Holmes, 26 F. Cas. 360 (C.C.E.D. Pa. 1842). Much of the philosophical literature focuses on the so-called "trolley problem." See, e.g., PhILIPPA FoOt, VIRTUES AND VICES AND OTHER ESSAYS IN MORAL PHILOSOPHY 19 (1978); JUdith JARVIS THOMSON, Rights, RESTITUTION, AND RisK 78, 94 1986). The defense of necessity also remains controversial in the context of prison escape. See, e.g., George P. Fletcher, Should Intolerable Prison Conditions Generate a Justification or an Excuse for Escape?, 26 UCLA L. REV. 1355 (1979).

61 See, e.g., Parry, supra note 48, at 416 ("Few would contest that a lost and starving hiker is justified in breaking into a cabin to obtain basic supplies ...").
} 
Commentary and cited in hundreds of other discussions of the defense. ${ }^{62}$ To the extent that there is any theoretical controversy here, it focuses primarily on the civil law question whether the intruder should be obligated to pay the owner compensation. ${ }^{63}$

Curiously, however, reported cases in which a defendant, charged with theft or trespass, was acquitted by virtue of the necessity defense are virtually nonexistent. Indeed, it is unusual for the defense even to be offered. The vast majority of the necessity-as-a-defense-to-trespass cases have involved what amounted to civil disobedience, where defendant protesters trespassed in order to obstruct the operations of a nuclear plant or a government building, and where the court typically held that the harm sought to be averted was insufficiently imminent or that legal alternatives existed. ${ }^{64}$ Also rare are cases in which necessity was recognized as a defense to theft. Even in those civil-disobedience-like-cases in which animal rights activists broke into a laboratory and stole animals on which experiments were about to be conducted, the defense was unsuccessful. ${ }^{65}$ Indeed, the case of Jean Valjean is doubly illustrative here. Victor Hugo's story of a man who steals a loaf of bread to feed his starving family is often cited as the paradigmatic example of a crime committed out of necessity. But it is worth recalling that, like almost every other case in which necessity has been asserted as a defense to charges of theft or trespass, Valjean's plea was unsuccessful.

\footnotetext{
62 Model Penal Code, Commentary to $\$ 3.02$, at 9.

63 See, e.g., Jules Coleman, Risks AND Wrongs 282 (1992); George C. Christie, The Defense of Necessity Considered from the Legal and Moral Points of View, 48 DUKE L.J. 975 (1999).

64 See, e.g., United States v. Schoon, 971 F.2d 193 (9th Cir. 1992).

${ }^{65}$ See generally James O. Pearson, Jr., Annotation, “Choice of Evils, ” Necessity, Duress, or Similar Defense to State or Local Criminal Charges Based on Acts of Public Protest, 3 A.L.R.5th 521.
} 
What accounts for this divergence between clear-cut theoretical acceptance and the realworld futility of necessity as a defense to theft? ${ }^{66}$ One possibility is that prosecutors are unlikely to bring charges of theft when it is clear that the defendant's acts were occasioned by grave distress. Another, more far-reaching, explanation is that the case-by-case, seemingly ad hoc nature of the necessity defense tends to cause "anxiety" among decision makers in the criminal justice system by, as John Parry puts it, "undermin[ing] the consistency and predictability that we often view as essential to the rule of law." ${ }^{67}$

One solution to this morass would be to draft statutes that specifically contemplate the circumstances in which the defense of necessity will be recognized. In other words, rather than leaving the question of necessity to generalized, broadly worded, "anxiety"-producing "choice of evils" provisions, where it is likely to be marginalized, we would do better to include provisions in our theft and trespass statutes that specifically enumerate the possible circumstances in which the defense of necessity might arise.

\section{Excusing Looting}

Having surveyed the moral content of looting at the two ends of the continuum, I now want to focus on those cases of looting that are neither so blameworthy that they deserve heightened punishment nor so justified that they should lead to exoneration. My interest here is in the circumstances that might make the defendant's conduct excused - whether completely or only partially. (I should note that, in the discussion that follows, I make no clear distinction

\footnotetext{
66 The discrepancy is also noted by Alan Brudner, A Theory of Necessity, 7 OXFORD J. Legal STUDIES 339 (1987).

67 Parry, supra note 48, at 403-04. Parry thinks that we should in fact welcome the ad hoc participation of the jury in this process as a means of promoting the moral conscience of the criminal justice system.
} 
between complete and partial defenses; instead, I assume that the same kind of circumstances can potentially justify both complete exoneration and mere mitigation. ${ }^{68}$ )

Although the precise logic of excuse defenses is controversial, I shall for present purposes subscribe to the view of excuses developed by Jeremy Horder. Under Horder's view, there are two kinds of conditions that must be satisfied in order for a claim of excuse in the criminal law to be successful. The first kind of condition he calls "necessary." According to Horder:

[I]t is a necessary condition of any claim to excuse that it is an explanation for engagement in wrongdoing (an explanation not best understood as a justification, as a simple claim of involuntariness, or as an out-and-out denial of responsibility) that sheds such a favourable moral light on D's conduct that it seems entirely wrong to convict, at least for the full offence. ... Excuses excuse the act or omission amounting to wrongdoing, by shedding favourable light on what D did through a focus on the reasons that $\mathrm{D}$ committed that wrongdoing. ${ }^{69}$

In addition, according to Horder, even if the first condition is met, a court should deny an alleged excuse unless a second, "sufficient" condition is also met. D's explanation for wrongdoing will not meet the sufficiency condition unless his case still seems compelling when the law's "strategic" goal of "maintain[ing] the integrity and flourishing of a common good" is taken into account. ${ }^{70}$ For present purposes, I shall focus on the first kind of Horder's conditions, while recognizing that consideration of the second kind of condition could substantially affect the ultimate outcome of a given case or category of cases.

\footnotetext{
68 For a useful discussion, see Douglas N. Husak, Partial Defenses, 11 CAN. J. L. \& JURIS. 167 (1998).

69 JEREMY HORDER, EXCUSING CRIME 8-9 (2004). For Horder, this is merely a necessary condition for any claim to excuse.

70 Id. at 15 . Strategic concerns include such matters as encouraging a culture of law-abidingness and political participation, avoiding intractable problems of proof, and maintaining a relationship of comity between the judicial and legislative branches. Id. at 16-17.
} 
What is important to note is that excuse defenses function quite differently from justification defenses like necessity. Whereas justification defenses consist of arguments that the defendant's conduct was not harmful or wrongful, excuse defenses focus on the culpability of the actor himself. Thus, to say that a given act of looting is excused is not to say that the looter's act was not wrong (in the way that a justified act is not wrong), but rather to say that the looter should not be held fully responsible for his conduct and should be exempt from punishment entirely or should have his punishment mitigated.

\section{The Case of the "Morally Ambiguous" Looter}

In order to test the applicability of excuse in the context of looting, let us imagine the case of what I shall call the "morally ambiguous" looter: $L$ is a 25 -year old African-American male who has grown up and lives in a high crime section of New Orleans East. Although he graduated from high school, his reading and writing skills are limited and the best job he has been able to find is that of a sales clerk for the local Wal-Mart, where he earns the minimum hourly wage of $\$ 5.15$. He suffers from asthma but has no health insurance. With his weekly salary of approximately $\$ 200$, he is barely able to pay for food, clothing, and the rent on the tiny apartment in which lives. He has no virtually savings. He owns no car. He spends several hours a day watching television and finds himself highly susceptible to advertising. There are numerous consumer products he would like to own, but cannot afford.

Although he grew up in New Orleans and still has family and friends there, $L$ feels little connection to the larger community in which he lives. He rarely votes in elections. The schools that he attended were sub-standard. Trash pickup in his neighborhood is irregular. The roads are 
in disrepair. Gun shots can often be heard after dark. Drug dealers operate openly. In general, $L$ feels that the system has let him down.

When he was in high school, $L$ was once arrested on a misdemeanor charge of marijuana possession. The charge was subsequently dropped and since then $L$ has avoided any involvement in criminal activity. Indeed, he has made a conscious decision in his life to "stay out of trouble."

On August 29, a hurricane strikes New Orleans. Although voluntary evacuation orders have been issued, $L$ has not been able to find transportation out of town. $L$ finds his neighborhood in chaos. Levees are breached and flood waters rise. Bedlam breaks out. Gangs of young men, including some whom $L$ knows from the neighborhood, break into stores and walk away with liquor, flat screen televisions, jewelry, and other luxury items. Some of $L$ 's acquaintances among the looters urge him to join them. Police are either nowhere to be seen or are standing by doing nothing.

At no point is $L$ without access to food, clean water, or other basic necessities needed to survive. But he is tired, scared, and anxious. His world seems turned upside down. Looters are breaking into stores and carrying out all the goods they can carry. It almost seems as if these goods, which in normal circumstances are well beyond $L$ 's limited purchasing power, are free for the taking.

Acting against the settled law-abiding course that he has set for himself in life, $L$ enters into the melee and participates in the looting of an electronics store. He steals a stack of DVDs, an IPod, and a laptop computer. The store from which $L$ steals is fully insured. He is subsequently arrested and charged with looting. The question is whether there might be an 
"explanation" for $L$ 's conduct such that he might be entitled, if not to a full excuse, then at least to a mitigation in his punishment.

\section{The Excuse of Acting "Out of Character"}

Traditionally, the law has maintained a relatively short list of available excuse defenses, consisting of duress, mistake, involuntary intoxication, insanity, and provocation (the last of which functions as a partial defense that mitigates murder to manslaughter). L's situation does not seem to qualify for any of these defenses. He has not been threatened with harm unless he commits a crime, as the duress defense requires. He is not unable to distinguish between right and wrong or to control his impulses, as the insanity defense requires. There is no evidence of intoxication. Nor can $L$ claim that he was actively misled into believing that his conduct was legal. ${ }^{71}$ Nevertheless, I believe that at least a partial excuse defense might be worked out on the grounds that $L$, in looting, acted "out of character.,"72

According to the character theory of excuse, an excuse will be available to a defendant to the extent that her action is not a manifestation of her character. The theory proceeds, in Victor Tadros' words, "from the principle that, although it is wrongful action that is its primary target,

\footnotetext{
71 Such a defense would amount to a claim of "entrapment by estoppel," in which the defendant argues that a government official has actively misled him into a reasonable belief that the conduct with which he is charged was legal. See, e.g., Cox v. Louisiana, 379 U.S. 536 (1965). The defense would not apply here because, although the police in my hypothetical stood by and did nothing, they did not affirmatively mislead $X$ into believing that his conduct was lawful. My thanks to Bob Blakey for pressing me to consider this point.

72 For present purposes, I shall not consider the more general argument that $L$ should be excused based on a history of economic deprivation or "rotten social background." For examples of such a "critical" approach, see ALAN W. NORRIE, LAW, IDEOLOGY AND PUNISHMENT: RETRIEVAL AND CRITIQUE OF THE LIBERAL IDEAL OF CRIMINAL JUSTICE (1991); Barbara Hudson, Mitigation for Socially Deprived Offenders, in PRINCIPLED SENTENCING 205 (Andrew von Hirsch \& Andrew Ashworth, eds., 1998); Richard Delgado, "Rotten Social Background”: Should the Law Recognize a Defense of Severe Environmental Deprivation?, 3 LAW \& INEQUALITY 9 (1985); see also generally From SOCIAL Justice TO CRIMINAL JUSTICE: POVERTY AND THE ADMINISTRATION OF CRIMINAL LAW (William C. Heffernan and John Kleinig, eds., 2000).
} 
criminal liability is justifiable only insofar as the character of the action is an expression of the character of the agent." ${ }^{.73}$ While recognizing that the character theory of excuses is hardly without its critics, ${ }^{74}$ I would like for the moment to accept its premise as a given, and proceed from there. In doing so, I rely heavily on Tadros' account. The claim at present is not that the "out of character" theory explains all excuse defenses across the board, but rather that it offers a good explanation for at least particular excuse defenses: involuntary intoxication and (the partial defense of) provocation. Let us consider each in turn.

Regarding the first, Tadros offers the following hypothetical: $D$, a devoted husband, becomes involuntarily intoxicated and while in that state goes through a marriage ceremony with another woman. He is charged with bigamy. Even in his intoxicated state, $D$ is still able to reason and control his impulses. But, Tadros says, the "fact that he had become intoxicated put him in a state where the reasons against marriage, reasons that grounded his devotion as a husband, did not motivate him where, ordinarily, they would have done." ${ }^{75}$ Thus, his denial of responsibility is based not on the claim that he lacked the capability to be a responsible agent, but rather on the idea that he was not really himself when he performed the act. And, therefore, "he," as a moral actor, should not be held responsible. ${ }^{76}$

\footnotetext{
73 See Victor Tadros, The Characters of Excuses, 21 OXFORD J. LEGAL STUDIES 495, 501 (2001); see also VICTOR TADROS, CRIMINAL RESPONSIBILITY 29 (2005). The character theory of excuses has been ascribed to a number of prominent thinkers, including, most famously, Hume. DAVID HUME, a TREATISE OF HuMAN NATURE, Book II, Part III, Section II. See also JoEl FeINBERG, DoING AND DESERVING: ESSAYS IN THE THEORY OF ResponsIBILITY 126 (1974); Michael Bayles, Character, Purpose and Criminal Responsibility, 1 LAW \& PHILOSOPHY 1 (1982).

74 These include Horder, see supra note 69; John Gardner, The Gist of Excuses, 1 BUFF. CRIM. L. REV. 575 (1998); R.A. Duff, Choice, Character and Criminal Liability, 12 LAW \& PHIL. 345, 361-80 (1993); Claire Finekstein, Excuses and Dispositions in Criminal Law, 6 BUFF. CRIM. L. REV. 317, 326 (2002).

75 Id. at 505. See also G.R. Sullivan, Making Excuses, in HARM AND CULPABILITY 131 (A.P. Simester \& A.T.H. Smith, eds. 1996) (offering analogous analysis of intoxication defense).

76 Id. at 506.
} 
Such a case, it should be noted, is very different from that in which $D$ voluntarily becomes intoxicated. The out-of-character theory requires that the defendant bear no responsibility for being in the condition that made him act like someone other than himself. If $D$ had voluntarily gotten drunk for the usual reasons that people get drunk - namely, to loose their inhibitions -- then he should have no claim of excuse.

Now let us consider the "out of character" theory in the context of provocation. Tadros offers another hypothetical: $D$ is normally a peaceful person. Even when she feels like being aggressive, she restrains herself because she subscribes to the "guiding reason that one ought not to use violence on another." ${ }^{, 77}$ But when she is provoked into a state of extreme anger, she is no longer as responsive to that guiding reason as she normally is. Her character when provoked is not like her character when calm, and actions done in that state do not reflect as badly on her settled character as if they had been done while calm. Once again, however, the defense is available only if $D$ is not responsible for the fact that she was provoked (for example, if she was short-tempered or went around picking fights).

So what help is all of this to $L$, our hypothetical looter? Is there some "out of character" excuse of which he might avail himself? $L$ would argue, first, that at the time of his looting he was in a state -- of fear, anxiety, peer pressure, and confusion - that caused him, while committing his act, to have a character that was different from his settled character. It is thus crucial to $L$ 's defense that he is ordinarily a law-abiding person who respects property rights. (A career criminal who uses the occasion of a hurricane to loot could not of course argue that his act was excused, since his act would not be out of character.) Second, $L$ would have to show that the reason he was in a mental state that caused him to act of character is attributable to factors for

77 Id. at 507. 
which he is not responsible. Here, the claim would be that $L$ 's relative poverty, the peer pressure from his neighbors, the lack of police vigilance, and the hurricane-induced inversion of social order are in fact the kinds of conditions for which $L$ cannot reasonably be said to be responsible.

\section{Practical Implications}

In the previous Part, I sought to demonstrate the wide array of moral judgments that attaches to different kinds of looting, ranging from a high level of disapprobation for certain cases of bad looting, to virtual approval of certain cases of good looting, with many cases in between. The question now is, how should the criminal justice system treat such a wide range of conduct? In an attempt to answer this question, this Part addresses three clusters of questions: (1) How should the responsibility for distinguishing between good, bad, and morally in-between kinds of looting be apportioned among legislatures, prosecutors, juries, and judges? Should looting be treated as a separate offense? Should such an offense be divided into different grades, such as "simple looting" and "aggravated looting"? (2) What factors should these various actors in the criminal justice system consider in deciding how to grade incidents of looting? What factors should be viewed as aggravating the seriousness of the defendant's act. What factors should be viewed as mitigating? What kinds of defenses, if any, should apply? (3) What should be the proper law enforcement response to looting? Can there be any justification for a generalized policy of "shooting looters"?

\section{A. Looting as a Distinct Offense}

As noted earlier, only seven U.S. jurisdictions currently have statutes that specifically make it a crime to engage in looting. In the other states, looting behavior is treated as a form of 
theft or burglary. The question thus arises: is there really any need for a specialized looting statute, and, if so, what should it look like?

Perhaps the most important principle in determining whether a particular type of criminal conduct requires its own statutory embodiment is that of fair labeling, the concern of which is, in Andrew Ashworth's words, to “see that widely felt distinctions between kinds of offences and degrees of wrongdoing are respected and signaled by the law, and that offences should be divided and labeled so as to represent fairly the nature and magnitude of the law-breaking., 78 The principle is intended to ensure a proportionate response to lawbreaking. "Fairness demands that offenders be labeled and punished in proportion to their wrongdoing." "79 Such labeling is important in determining the appropriate punishment, for evaluating prior convictions, and, perhaps most importantly, in sending the appropriate signal to the public.

If a single criminal label reflects too broad a range of moral content, there is a danger that less serious incidents of crime will be treated too harshly, and more serious incidents too leniently. Hence, it is often desirable to refine our offense classifications to make them more responsive to such concerns. For example, the broadly defined offense of "homicide" has long since been divided into the more narrowly defined offenses of "murder," "manslaughter," and "negligent homicide." All three offenses involve essentially the same form of harm (namely, the death of a human being). But they differ in other significant forms of moral content. Murder is more serious than involuntary manslaughter because it involves a higher level of mens rea, and is more serious than voluntary manslaughter because it involves a more serious form of moral wrongfulness. One can easily imagine a regime in which the legislature created a single

\footnotetext{
78 ANDREW ASHWORTH, PRINCIPLES OF CRIMINAL LAW 89-90 (4th ed. 2003).

79 Id. at 90.
} 
overarching offense of "homicide," and in which relatively fine distinctions between murder and manslaughter were made only at the time of sentencing. But such a regime would be subject to the complaint that it left too much discretion to the sentencing judge and provided insufficient notice to potential offenders. In short, murder deserves to be treated separately from manslaughter because it is morally distinct from manslaughter, and because it would be unfair and confusing to treat murderers and manslaughters the same.

When new patterns of criminality emerge, or are newly recognized, we often isolate them by creating new offenses. For example, while the relatively new offense of carjacking could have been treated as simply another means of committing the previously existing offense of robbery, many legislatures have thought that a separate offense was called for. A similar pattern can be observed in the case of fraud (now frequently subdivided into offenses such as bank fraud, computer fraud, securities fraud, bankruptcy fraud, and accounting fraud).$^{80}$

The argument for codifying looting separately from burglary and larceny follows a similar logic. The harms that it causes, the circumstances that give rise to it, the censure that it elicits, and the potential defenses that it implicates all mark looting out as a distinctive crime.

Moreover, even in terms of its basic elements, looting is distinguishable from burglary and larceny. Looting has elements that are not a part of burglary or larceny, and larceny and burglary have elements that are not a part of looting. Like looting (on least in its most common formulation), burglary requires an unauthorized entry, but, unlike looting, it requires no actual taking once inside. Larceny, on the other hand, does require a taking, but it does not require an

${ }^{80}$ I deal in some detail with the question of when it is appropriate to create new offense labels in Stuart P. Green, Prototype Theory and the Classification of Offenses in a Revised Model Penal Code: A General Approach to the Special Part, 4 BUfF. CRIM. L. REV. 301 (2000). The issue is also addressed in Victor Tadros, The Distinctiveness of Domestic Abuse: A Freedom-Based Account, in DefinIng CRIMES: ESSAYS ON THE SPECIAL PART OF THE CRIMINAL LAW (R.A. Duff \& Stuart P. Green, eds. 2005) 119, 131-38 (considering whether domestic abuse should be treated as a discrete offense). 
unauthorized entry. Most importantly, neither burglary nor larceny requires emergency

conditions which lead to the absence of normal security and all of the moral complexity that such circumstances create, including potentially greater threats to public order and safety, the lack of sympathy and predatory character of the looter's acts, and other aggravating and mitigating factors of the sort that we shall now consider.

\section{B. Aggravating and Mitigating Factors}

Assuming that my argument above is correct, and that a specialized looting statute is needed to satisfy the principle of fair labeling, the next question is how such a statute should be formulated and applied. In constructing such a statute, I would begin with a modification of the basic elements present in current looting statutes. First, I would require that the normal security of property be absent by virtue of some natural disaster or civil disturbance. Second, for the reasons discussed above, I would require that the looter steal (as opposed to merely damage) the property of another. Third, also for the reasons explained above, I would be inclined to eliminate the requirement that the looter make an unauthorized entry into a home or business, but I would perhaps leave such entry as an aggravating factor.

The interesting question, though, is what additional elements, if any, such a statute should include. Should it contain an explicit exception for "necessitous" looting, the way some prison escape statutes provide an exemption for escapes that involve a "danger to human life." 81 Should it be divided into grades - say, "aggravated" and "simple," or "first degree" and "second degree," looting? Should it have a list of aggravating and mitigating circumstances that would determine the ultimate range of sentencing?

81 See, e.g., La. Rev. Stat. § 14:110. 
One possibility is that the kinds of factual distinctions I am seeking to make between different kinds of looting are too fine to be written into statutory form and are best left to the discretion of prosecutors, juries, and sentencing judges. Under this approach, the legislature would simply lay out the basic elements of the crime and leave the work of making such finer distinctions to other actors within the criminal justice system. ${ }^{82}$

To raise this issue is to invite a discussion of difficult and controversial issues concerning legality, the separation of powers, judicial activism, and the like, most of which lie beyond the scope of my analysis. (For what it's worth, my own instinct is that, under the principle of fair labeling, legislatures have an obligation to distinguish not only between different kinds of offenses but also between different grades of a given offense and, perhaps, to identify which defenses, if any, are likely to apply.)

For the moment, my goal is simply to identify those factors that various decision makers in the criminal justice system - whether legislatures, prosecutors, judges, or juries -- ought to take into account in distinguishing between more and less blameworthy cases of looting. I divide them into eleven factors. Factors 1-6 involve primarily the offender's own circumstances. Factors 7-11 involve primarily the effects of his acts.

1. Nature of looter's need. An important factor in determining mitigation and aggravation is the nature of the looter's need for the goods stolen. We would want to ask, how

\footnotetext{
82 One of the few scholars to address this issue is ITZHAK KUGLER, DIRECT AND OBLIQUE INTENTION IN THE CRIMINAL LAW 114-16 (2002). Kugler identifies a number of factors that tend not to be (and apparently in his view, should not be) included in legislative definitions of offenses, but instead are considered by the judge at sentencing. He gives as examples the amount of harm caused, the motives of the actor, his criminal record and personal characteristics (e.g., his age, education, mental impairment), and the likelihood that the offender can be rehabilitated. While I agree with Kugler's basic approach to the problem, however, I disagree with some of his specific claims. For example, legislative definitions of theft and drug offenses, at least in American law, often include distinctions based on the value of goods stolen or the amount of drugs possessed or sold; recidivist statutes frequently enhance the penalty based on the offender's criminal record; and hate crimes statutes enhance the penalty based on a specific kind of motive in the offender.
} 
serious was the emergency in which the looter found himself? How serious was his need to steal? Would he or someone in his family have starved, or gotten sick, or suffered from exposure without them? Or was the looter well-supplied and well-provisioned even without his looting? Could the looter have obtained the stolen goods from other (lawful) sources? Was the looter employed? Did he have the means to evacuate? How isolated was the looter from relief teams? How panicked was he? Did the looter have reason to believe that help was on the way? To the extent that the looter's needs were shown to be real and urgent, his conduct would be viewed as less culpable.

2. Nature and quantity of goods taken. A second factor is the nature and quantity of the goods stolen, damaged, or destroyed. In general, we would view the looting of necessities like food, basic clothing, and needed prescription medications as less culpable than the looting of luxury items like DVD players, jewelry, and alcohol (though we should be aware of the possibility that such luxury goods might in some cases be used a means to barter for necessities). Even worse would be the looting of guns, narcotics, and other dangerous instrumentalities (although even here one could imagine a case in which a storm survivor might steal a gun or other weapon in order to defend himself from intruders). We would also want to know whether the items, if not taken, would be salvageable after the emergency had passed. For example, other things being equal, the looting of perishable food items like milk and bread seems less harmful than the looting of non-perishable items like canned goods and cookware. In addition, we would want to know the quantity of goods taken or damaged. A looter who took only enough to survive until the emergency passed would surely be viewed as less culpable than one who took a larger quantity than he himself could use; a reasonable inference would be that such a person was taking such goods with the intent to profit from them. 
3. Looter's willingness to compensate victim for losses. Another question we would want to ask is whether the looter subsequently expressed his willingness to pay for the goods taken (assuming he is able to do so), particularly prior to his being arrested and prosecuted. Such willingness would seem to provide prima facie evidence that the offender did not intend to profit from his acts and that they were in fact the product of necessity.

4. Looter's role in group conduct. A fourth factor is whether the looter was acting alone or in concert with others. Assuming that she was acting with others, we would want to inquire into her role in the group. Was the looter a ringleader who precipitated a wave of looting by others, or was she merely a follower who began looting only after others in her community had already done so? Was the looting done pursuant to an express or implicit agreement, or were the looters acting out of a spontaneous mob impulse? In general, we would tend to view collective and premeditated action as more culpable than individual and impulsive action.

5. Role of law enforcement. A fifth factor involves the role of law enforcement. Here, we would want to ask, did police or other law enforcement officials stand by, acquiescent, while looting was being perpetrated? To the extent they did, we would want to ask whether the looter was reasonable in interpreting such conduct as a kind of authorization to engage in such conduct. We would also want to know if this was a case in which police themselves were participating in the looting. ${ }^{83}$ If so, such conduct by police should be treated very harshly.

6. Offender's criminal history. A court or prosecutor might also want to inquire into the offender's criminal history. A looter with a long criminal record of similar acts would

\footnotetext{
83 Among the hundreds of incidents of looting reported in the wake of Hurricane Katrina, at least a dozen were alleged to have involved New Orleans police officers. See Witnesses: New Orleans Cops Among Looters, CNN.COM (Sept. 29, 2005), http://www.cnn.com/2005/US/09/29/nopd.looting/.
} 
presumably have a weaker argument that her looting was a one-time, "out of character" deviation from her usual law-abiding self.

7. Vulnerability of victim. Another important factor in assessing the moral content of looting would be the vulnerability of the victim. In general, we would expect that the more serious the disaster or civil disturbance, the more likely that victims would be without normal security and the more vulnerable they would be.

\section{Nature of premises into which entry (if any) is made and from which goods are}

taken. An eighth factor in assessing the seriousness of a particular act of looting would be the nature of the premises, if any, into which the looter made an unauthorized entry and from which goods were misappropriated. For example, we would want to know if the looter entered a private home, a local mom-and-pop shop, a government building, or a national chain store. Presumably, the smaller and more vulnerable the victim, the more significant the harm and the greater its effect on the local community. One of the concerns here would be with the possibility that extensive looting might eventually lead to store closings, lost jobs, increased insurance premiums, and higher prices for residents of the affected community.

9. Nature of violation of property rights. A ninth factor is the kind of property rights that the looter violates. Most looters carry goods away with the purpose of depriving their owner of them permanently. In other cases, the looter will destroy or damage goods. In yet other cases, the looter will merely "borrow" goods. Presumably, borrowing goods without permission is a less serious violation of property rights than stealing or destroying them.

10. Harm to victim and community generally. Another set of factors we would want to assess involves the (foreseen or foreseeable) effects of the looter's acts on his victims and on the community more generally. We would want to know whether the defendant's looting posed 
a danger to anyone's health or safety. Was the owner present when the looting took place? Did the looter take goods that could not easily be replaced? Were the goods insured against theft or damage? How disruptive was the looting to the community in which it was perpetrated? How much did the victim need the goods taken by the looter?

11. Protest movements, food riots, and political transition. Finally, as seen in the recent case of disaffected youths in France, looting and rioting often accompany protest movements. Looting has played a particularly particular prominent role in "food riots" in Argentina, Pakistan, Zimbabwe, and elsewhere, where citizens were protesting increases in food prices. Looting also sometimes accompanies the transfer of political power, especially in cases where a despotic regime has suppressed dissent and maintained close control over the distribution of wealth, as can be seen in connection with the downfall of Saddam Hussein. In determining whether such surrounding activity should mitigate (or aggravate) the wrongfulness of looting, we would want to inquire into the merits of the protest. Looting done as part of a legitimate movement to bring about genuine political reform or liberation should be viewed as less blameworthy than looting done as part of a scheme to cause chaos or oppression, although, admittedly, determining which kind of protest is which is likely to be the subject of controversy. ${ }^{84}$

In sum, where the mitigating circumstances of the defendant's acts are compelling (e.g., the emergency was serious, the offender stole only enough goods to survive and such goods were in any event perishable, and where he was one of the last to participate in the looting), the statute should provide a complete defense. On the other hand, where the aggravating circumstances

84 For an example of such an argument, see Sergio Serulnikov, When Looting Becomes a Right: Urban Poverty and Food Riots in Argentina, 21 LATIN AMERICAN PERSPECTIVEs 69 (1994). See also Robert M. FogELSON, ViOLENCE AS PROTEST: A STUDY OF Riots AND GHETTOS (1971). 
were serious (e.g., the offender took large quantities of luxury goods which he intended to sell for a profit, and he was one of the first to loot), the penalties should be more severe than in the case of simple larceny or burglary. Those acts that lie somewhere in between should be subject to relatively light penalties.

\section{Law Enforcement Response: "Shooting Looters"}

Even before a suspected looter comes into contact with prosecutors, judges, and juries, he will likely encounter the police. A final issue that needs to be considered, then, is the appropriate law enforcement response to acts of looting at the scene of the crime. Although the moral content of the looter's act is not relevant here in quite the direct way it is in determining whether and how the act should be treated by prosecutors, judges, and juries, it will nevertheless constitute a relevant consideration in determining the appropriate police response.

In the wake of Hurricane Katrina, various "conservative" media commentators, including Peggy Noonan (writing on the op-ed page of the Wall Street Journal), suggested that the most appropriate response to looters is to shoot them on sight. ${ }^{85}$ Sometimes the suggestion was that such shootings be done by the police. ${ }^{86}$ Other times, it was suggested that looters be shot by private citizens. ${ }^{87}$ Even more striking, there is evidence that the shooting of looters was for a

\footnotetext{
85 Noonan, supra note 8.

86 Mona Charen, Shoot Looters, TownHALl.CoM (Sept. 2, 2005), $<$ http://www.townhall.com/opinion/columns/monacharen/2005/09/02/155214.html > ("If police officers are authorized to shoot looters, this intelligence will spread quickly among the criminal population. The free-for-all will come to an abrupt end.").

87 David Kopel, Armed Response to Looters, THE VOLOKH CONSPIRACY, $<$ http//volokh.com/posts/chain_1125597101.shtml $>$ "Given the absence of a sufficient police presence in order to stop the looters, I strongly agree ... that such looters should be shot on sight by armed citizens.”).
} 
time the accepted policy of U.S. occupation forces in Iraq. ${ }^{88}$ In this final section, I want to examine the arguments, such as they are, for and against a policy that would authorize such shooting of looters.

We begin with the rule, pervasive at least in Anglo-American jurisprudence, that deadly force may not be used in defense of property, even when it is the only means available to prevent the loss. ${ }^{89}$ This rule is consistent with the more general rule that defensive force must be proportional - i.e., not excessive in relation -- to the harm threatened. Naturally, where the looting of property is combined with behavior that involves an imminent and deadly threat to a person, there is no question that deadly force would be allowed. But our focus here is on what we might call "pure looting," in which the only threat is to property. The question is whether there is something special about the threat posed by looting that would distinguish it from the threat posed by other property crimes, such as burglary and theft, and thereby justify the use of deadly force.

At first glance, it might seem as if the use of deadly force in response to looting could be justified along lines similar to those that have been used to justify the use of deadly force in

88 On May 14, 2003, the New York Times reported on a "tough new security setup" in Iraq under the then-new American Administrator L. Paul Bremer. The Times quoted an unnamed American official describing a meeting he had attended at which Bremer laid out the new policy. The official told the Times, "I think you are going to see a change in the rules of engagement within a few days to get the situation under control." Asked what this meant, the official replied, "They are going to start shooting a few looters so that the word gets around" that assaults on property ... will be dealt with using deadly force." Tyler, supra note 9, at A1. Two days later, the Times quoted Defense Secretary Donald H. Rumsfeld describing as "hyperbole" the May 14 article reporting that American forces would have the authority to shoot looters on sight. Rumsfeld was quoted as saying, "[w]e have rules of engagement - have had, do today. They've not been changed. [Those rules] permit 'the use of whatever force is necessary for self-defense or for other selected purposes."' Patrick E. Tyler, Aftereffects: Law and Order; American Troops Step Up Efforts to Curb Crime and in Iraqi Capital, N.Y. TIMES (May 16, 2003), at A16. Whether such "other selected purposes" include the shooting of looters who threaten property alone remains unclear. In any event, shooting looters in Iraq was clearly the approach recommended by Fox News commentator Bill O'Reilly. See Bill O'Reilly, Shoot to Kill, FOX NEWS.COM, http://www.foxnews.com/printer friendly story/0,3566,86967,00.html ("[I] urge the Pentagon to stop the P.R. dance and impose strict rules of conduct for the Iraqi people to follow. . . . Shoot looters to kill, and aim well.”).

89 Wayne R. LaFave, CRiminal Law (4th ed. 2003). See also Joshua Getzler, Use of Force in Protecting Property, _ J. THEORETICAL INQUIRIES IN LAW 131 (2005). 
defense of dwellings, a topic that I have dealt with in detail elsewhere. ${ }^{90}$ But even if the use of deadly force in such circumstances could be justified (a proposition about which I have previously expressed a good deal of skepticism ${ }^{91}$ ), the rationale that underlies such use of force would not apply to the typical case of looting. The defense of premises doctrine is based on a series of assumptions about the special dangers and interests and vulnerabilities that supposedly (and, in my view, questionably) attend unlawful entry when the homeowner/defender is present in the home being invaded.

Thus, there are at least three reasons why a defense-of-premises-type rationale would not apply to the vast majority of looting cases. First, looting rarely occurs when the home or business owner is present in the premises being invaded. ${ }^{92}$ Second, the kind of "looter shooting" that commentators such as Noonan have in mind seems unlikely to occur inside premises, whether or not occupied. The kind of action that seems to be contemplated involves suspected looters who are running down the street, carrying allegedly stolen goods, in the open. Finally, the defense of premises doctrine usually requires that the defender warn the intruder to desist

\footnotetext{
${ }^{90}$ Stuart P. Green, Castles and Carjackers: Proportionality and the Use of Force in Defense of Dwellings and Vehicles, 1999 U. ILL. L. REV. 1.

91 In the work cited, $i d$. at 24-41, I considered the validity of five arguments in favor of allowing such force: (1) a deadly threat should be presumed whenever an intruder unlawfully attempts to enter a defender's dwelling; (2) defenders are more vulnerable in the home than elsewhere; (3) defenders have a specially privileged property interest in the home; (4) an intrusion into a defender's premises involves a threat to privacy, dignity, and honor analogous to the threat present $\mathrm{n}$ crimes such as rape and kidnapping; (5) the use of deadly force in defense of premises is justified as a means of deterring unjustified aggression and punishing criminal behavior. I argued that none of these conditions, standing by itself, is sufficient to sustain the defense of premises doctrine, premised as they are on unsupported empirical assumptions about the dangers posed by intrusions into the home, an improper conflation of the rules of proportionality and necessity, troubling comparisons between the value of human life and the value of property, and other errors. I then concluded that the requirement of proportionality might nevertheless be satisfied by an aggregation of such interests.

92 Of course, there might be cases in which the looter is mistaken in his belief that the premises have been vacated; in such cases, the defense of premises doctrine would normally apply.
} 
(and that the intruder fail to do so) before deadly force can be used. ${ }^{93}$ The suggestion that looters be shot "on sight" obviously implies that no such warning would be given.

The question, then, comes down to this: Is there something about "looting" property, as opposed to merely "stealing" it, that would justify a departure from the traditional rule against using deadly force in defense of property? If my argument in Part II is correct, looting (or at least "bad looting") should indeed be viewed as a more serious crime than ordinary theft or burglary. It involves a kind of exploitative and predatory behavior that is significantly more blameworthy than these other offenses. And the harms it causes go well beyond the loss of property or invasion of property involved in "routine" theft and burglary. As I argued above, looting is as much a crime against public order as it against property. It is both a cause and a consequence of anarchy. More than almost any other crime, looting reflects a breakdown in social norms. It should, as I suggested, be punished severely.

But to recognize all this is a far cry from saying that the routine shooting of looters would be justified. The fact is that punishment and law enforcement are two very different kinds of institutions. ${ }^{94}$ Punishment in our system is imposed only after the defendant has been convicted by a unanimous jury based on proof beyond a reasonable doubt. Law enforcement, by contrast, is carried out in the heat of the moment, often by a single official, based on incomplete information. Neither police nor civilians are empowered to use force to punish; they are authorized to use such force only to protect public safety, apprehend suspects, and conduct

\footnotetext{
93 Green, supra note 90, at 12.

94 The classic case is Tennessee v. Garner, 471 U.S. 546 (1985) (holding that use of deadly force to prevent felony suspect's escape is unconstitutional unless officer had probable cause to believe that suspect posed a significant threat of death or serious physical injury to the officer or others). $C f$. GEORGE P. FlETCHER, THE GRAMMAR OF CRIMINAL LAW: AMERICAN, COMPARATIVE, INTERNATIONAL - VOLUME 1: FOUNDATIONS (manuscript on filed), at 17 (explaining theoretical distinction between punishment and self-defense).
} 
investigations. Where looting is aimed solely at property, and involves no specific threat of harm to any person, there is simply no rationale for responding with deadly force. ${ }^{95}$

There is a real danger that an overaggressive police response to looting will result in overdeterrence. Persons who genuinely qualify for the necessity defense might forgo the opportunity to engage in justified looting if they believe there is a good chance that they will be gunned down in the process. As illustrated by the two photos with which this article began, distinguishing between good and bad looting on the basis of superficial appearances can be difficult. Even if the looter is observed carrying away luxury items such as jewelry or electronic equipment, it cannot necessarily be assumed that his looting is bad: He might well plan to barter such items for basic necessities such as food and medicine.

Moreover, racial prejudice plays a particularly problematic role. It seems obvious that young African-American males are more likely than whites to be mistakenly suspected of bad looting, and they are therefore also more likely to be mistakenly shot by overzealous law enforcement officials. As in the case of wrongful executions, wrongful killings by police (and civilians) are irreversible. Deadly force should never be used to stop looters who threaten nothing more than property.

\section{Conclusion}

The concept of looting encompasses a remarkably broad range of behaviors, possibly unique in all the criminal law. At its most reprehensible, looting is predatory, merciless, and

\footnotetext{
95 Alternatives to deadly force are discussed in the Report of the Kerner Commission, the federal body created by President Johnson to investigate the causes of the 1967 race riots in the United States. See REPORT OF THE NATIONAL AdVISORY COMMISSION ON CIVIL DisORDERS 176-77 (March 1, 1968) (recommending that police respond to civil disorders by using nonlethal tear gas, sticky tapes, adhesive blobs, liquid foam, intensely bright lights, and loud distressing sounds).
} 
productive of anarchy. At its most forgivable, it offers an accepted means of survival in emergency circumstances. In between are instances of looting which, if not justifiable, may be at least partially excusable. Current law does a poor job of accommodating such moral complexity. Looting is ordinarily treated as just another form of burglary or theft, the necessity defense is construed extremely narrowly, and in the handful of states that do make looting a distinct crime, the statutes offer no real basis for distinguishing the bad from the good.

Sadly, in a world plagued by increasing inequalities in wealth, terrorism, and globalwarming-induced weather disasters, looting is a phenomenon that is likely to be with us for some time. Some commentators have reacted with inflammatory calls to "shoot looters on sight." The framework developed here offers the basis for what I believe is a far more rational approach to the problem. 